\title{
A prática musical religiosa no Brasil e em Portugal na segunda metade do século XVIII: paralelo e fundamentação para a interpretação vocal da música de José Joaquim Emerico Lobo de Mesquita
}

\author{
Katya Beatriz de Oliveira (UNIRIO, Rio de Janeiro, RJ) \\ katybia@hotmail.com \\ Laura Rónai (UNIRIO, Rio de Janeiro, RJ) \\ laronai@pobox.com
}

\begin{abstract}
Resumo: Na busca da sonoridade histórica e estilisticamente embasada para a interpretação vocal da música sacra mineira da segunda metade do século XVIII e início do XIX, torna-se necessário um paralelo com a música realizada em Portugal durante o século XVIII, que constate a influência desta sobre a música mineira setecentista. Neste artigo pretendemos investigar as similaridades estilísticas entre a música do compositor mineiro José Joaquim Emerico Lobo de Mesquita, particularmente no solo de soprano de sua Missa em Mi bemol, com o solo de soprano de uma Missa a cinco vozes do compositor David Perez e o primeiro movimento do moteto Care Deus si respiro, para soprano solo e cordas, de Niccolò Jommelli, compositores italianos da escola napolitana atuantes em Portugal na segunda metade do século XVIII. Temos como objetivo justificar a utilização de tratados europeus para a fundamentação dos aspectos interpretativos da música mineira.

Palavras-chave: música brasileira; música sacra; interpretação vocal; música historicamente informada; Lobo de Mesquita.
\end{abstract}

Religious musical practice in Brazil and Portugal in the second half of eighteenth century: parallels and basis for the vocal interpretation of the music of José Joaquim Emerico Lobo de Mesquita

Abstract: In order to achieve a historically and stylistically-based vocal interpretation of the sacred music of Minas Gerais (Brazil) in the second half of the eighteenth century and early nineteenth century, it is necessary to compare it with Portuguese music written during the same period, thus tracing the Portuguese influence in the Brazilian works. In this essay we intend to investigate the similarities in style between the music of the composer from Minas Gerais José Joaquim Emerico Lobo de Mesquita, particularly in the soprano solo of his Mass in E flat, and the soprano solo of a Mass for five voices by David Perez and the first movement of the motet Care Deus si respiro, for soprano solo and strings, by Niccoló Jommelli, Italian composers of the Neapolitan school who worked for the Portuguese court in the second half of the 18th century. We will therefore attempt to justify the use of historical European singing treatises to use as basis for the vocal performance of this music from Minas Gerais.

Keywords: Brazilian music; sacred music; vocal performance; historically informed music; Lobo de Mesquita. 


\section{1 - Introdução}

No presente artigo pretendemos verificar a influência da música realizada na corte portuguesa, na segunda metade do século XVIII, sobre a música de José Joaquim Emerico Lobo de Mesquita, compositor mineiro possivelmente nascido no Serro em meados do século XVIII e com importante atuação na região de Diamantina (antigo Arraial do Tejuco). Para tal realizamos um paralelo entre o solo de soprano de sua Missa em Mi bemol, o solo de soprano de uma Missa a cinco vozes do compositor David Perez e o primeiro movimento do moteto Care Deus si respiro, para soprano solo e cordas, de Niccolò Jommelli, compositores italianos da escola napolitana atuantes em Portugal na segunda metade do século XVIII. Temos como objetivo justificar a utilização de tratados europeus como os de Pier Francesco Tosi ${ }^{1}$ (Itália), Giambattista Mancini ${ }^{2}$ (Itália), Johann Adam Hiller ${ }^{3}$ (Alemanha), Johann Joachim Quantz ${ }^{4}$ (Alemanha) e Manoel de Moraes Pedroso ${ }^{5}$ (Portugal) para a fundamentação dos aspectos interpretativos da música mineira deste período, considerando-se que a Imprensa no Brasil somente surgiu a partir da chegada da familia real em 1808.

Notificação da Ordem Régia de 1747:

"Não imprimissem livros, obras ou papéis alguns avulsos, sem embargos de quaisquer licenças que tivessem para a dita impressão, sob pena de que fazendo o contrário, seriam remetidos presos para o Reino para se Ihes impor as penas em que tivessem incorrido (...)" (apud SODRÉ, 1999. p.17-18).

\section{2 - A música em Portugal no século XVIII}

A música religiosa e a ópera constituem os dois principais vectores que direcionaram a maior parte da produção portuguesa ao longo do século XVIII, correspondendo a promoção destes gêneros musicais ao desenvolvimento de diferentes estratégias de afirmação do poder monárquico. (FERNANDES, 2005, p.52).

Com a subida ao trono do Rei D. João V, a Capela Real, instituição religiosa sob o domínio direto do monarca, ganhou um grande destaque, chegando a possuir "setenta e um cantores (italianos e portugueses), quatro organistas e um compositor italiano" no ano de 1747. A grande dimensão do cerimonial religioso se tornou uma das estratégias de representação do poder real. A contratação de músicos profissionais de alto nivel, principalmente italianos, a criação de instituições pedagógicas para a formação de músicos portugueses e o envio dos estudantes que se destacavam nestas instituições para a realização de estudos na Itália, ocasionou uma mudança significativa no cenário musical português, agora sob grande influência italiana. Ao mesmo tempo, toda a pompa do cerimonial religioso acabou por coibir a manifestação do espetáculo da ópera. (FERNANDES, 2005, p.53-55).

Uma grande virada se operou com a subida ao trono do rei D. José, em 1750. Um aficcionado pela ópera, privilegiando o gênero, contratando um dos mais prestigiados compositores de ópera séria de seu tempo, o compositor David Perez (1711-1778), e construindo o novo teatro de ópera da corte, a Casa da Ópera, inaugurada com a apre- sentação da ópera de Perez, Alessandro nell'Indie, uma grande produção com os maiores cantores italianos daquele período.

Com o terremoto que ocorreu em Lisboa em 1755, o luxuoso teatro de ópera foi destruído poucos meses depois de sua inauguração, interrompendo as montagens por oito anos. Encarregado da reconstrução de Lisboa, o Marques de Pombal não inclui o teatro de ópera nem a Capela Real em seus projetos de reconstrução. Assim, a corte portuguesa transferiu-se para a cidade de Ajuda e a retomada das atividades operísticas passou a acontecer nos modestos Teatro da Ajuda e Teatro de Salvaterra. A Capela Real e a Patriarcal, anteriormente unificadas, passam a funcionar em locais diferentes.

As relações com a Itália continuavam intensas, com cantores italianos contratados tanto para as atividades religiosas, quanto para as montagens das óperas. Jovens músicos portugueses também continuavam sendo enviados para se aprimorar na Itália, agora em Nápoles.

No reinado de D. José, o estado se distanciou um pouco mais da Igreja, com a ópera ocupando uma posição de maior destaque, mas ainda assim a pompa das cerimônias religiosas continuou a florescer, com os principais compositores contratados pela corte escrevendo música tanto para o serviço religioso, quanto para a ópera (FERNANDES, 2005, p.55-58).

A grande influência exercida pela escola napolitana sobre a música portuguesa se dava particularmente pelos serviços de David Perez e Niccolò Jommelli, dois importantes compositores italianos da escola napolitana. 0 primeiro, residente em Portugal desde a sua contratação em 1752, o segundo, contratado pela corte portuguesa em 1769, com a obrigação de enviar anualmente para Portugal uma ópera seria e uma buffa, além de composições para o serviço religioso.

Para as principais festividades religiosas, tanto na $\mathrm{Ca}$ pela Real e na Patriarcal, como nas Igrejas e outras Instituições religiosas, eram convocados músicos da Orquestra da Real Câmara, que chegou a contar com 51 músicos entre 1773 e 1782, tornando-se a maior orquestra de corte da Europa. Eram interpretadas, além das obras de Perez e Jommelli, obras de compositores como Domenico Scarlatti, Leonardo Leo, Leonardo Vinci, Niccolò Porpora, Francesco Durante, Giovanni Battista Pergolesi ou Benedetto Marcello. Como observa FERNANDES $(2005$, p.65):

\footnotetext{
A sociedade lisboeta setecentista deleitava-se nas várias festividades religiosas, que assumiam por vezes o caráter de uma curiosa mistura entre o sacro e o profano, quer em termos visuais, quer musicais. [...] Esta interpenetração entre o sagrado e o profano caracterizava-se, com frequência, por uma certa atmosfera teatral evocadora do espetáculo operático e que tomava forma por via do aparato cerimonial inerente ao ritual litúrgico, das caracteristicas da música, da exibição virtuosística dos cantores da Capela Real [...] e da dimensão cenográfica decorrente da decoração e da iluminação das próprias Igrejas.
} 


\section{3 - 0 cenário musical em Minas Gerais no século XVIII}

Com a proibição por parte do rei de Portugal da instauração das ordens primeiras 6 em Minas Gerais, com o objetivo de evitar a evasão do ouro, surgiram as irmandades ${ }^{7}$ que patrocinaram as artes ligadas ao serviço religioso. Além disso, a imigração de pessoas de diferentes partes do Brasil e de europeus, principalmente portugueses, em busca do tão procurado metal, propiciou a importação de produtos, como louças, livros, instrumentos musicais, partituras, etc., favorecendo o surgimento de uma sociedade culta e informada a respeito do que estava em voga na Europa. John MAWE (1978, p. 176), viajante inglês que obteve a permissão do Príncipe regente D. João para visitar Minas Gerais entre 1809 e 1810, relata:

\begin{abstract}
As familias que tive a honra de visitar me pareceram bastante sociáveis, e muitas vezes se oferecem chás. Os trajes femininos são inteiramente de artigos ingleses, algodão estampado, chapéus de palha, flores artificiais, jóias, etc. 0 grande afastamento de um porto de mar é a causa de não haver ainda no Tijuco um piano. Se não fosse isso, estes instrumentos ai teriam grande procura, porque as senhoras em geral gostam de música e tocam o violão com muito sentimento e graça.
\end{abstract}

Apesar de não serem permitidos Conventos e Mosteiros nas Minas, havia a presença de padres seculares ${ }^{8}$, que era necessária para a realização dos serviços religiosos e da catequização da comunidade. "Os padres mineiros do século XVIII ou eram formados em Portugal, no Rio de Janeiro ou no Seminário de Mariana." (MOREIRA, 2006, p.56).

Pela primeira vez se estabelecia no país uma sociedade plenamente urbana, na qual a oportunidade de enriquecimento permitia a ascensão de indivíduos de determinadas classes - como escravos e mestiços, além dos brancos não nobres - que jamais outrora haviam tido essa possibilidade.

\begin{abstract}
A organização social das Minas Gerais não compreendia apenas senhores e escravos, como no litoral açucareiro, em que a sociedade se bipolarizava. A mineração dava oportunidade ao enriquecimento rápido. Até mesmo os escravos se beneficiavam dela, pois tinham oportunidade de, trabalhar por conta própria e comprar a carta de alforria que os tornava homens livres. Como camada intermediaria, entre proprietários e escravos, apareciam artesãos urbanos, músicos, pintores e escultores, quase todos mestiços, mas havia, também, alguns homens brancos despossuídos. No vértice da pirâmide social mineira situava-se a elite, formada por indivíduos brancos, letrados, ricos potentados, proprietários, funcionários do governo, militares de patente e grandes comerciantes que, segundo diz Boschi, enviavam os filhos para estudar na Universidade de Coimbra (...) (VALADARES, 2004, p.270-271).
\end{abstract}

As cidades serviam como cenário para inúmeros cortejos, procissões e festas, que chegavam a durar vários dias, se transformando em palco para as manifestações religiosas e para a publicidade do poder real (FURTAD0, 2009, p.139). Com todo esse dinamismo sócio-cultural, nos deparamos primeiramente, com música europeia trazida por padres e artistas. Numa segunda instância, encontramos música de portugueses já vivendo no Brasil ou dos próprios brasileiros, já instruídos, influenciados por essa música europeia. $A$ arte patrocinada pelas irmandades é entregue principal- mente aos mestiços, que através dela tem a sua possibilidade de ascensão e de aceitação pela comunidade.

0 sistema colonial apoiava-se basicamente na exploração dos homens, resultando em relações de autoridade, dos brancos sobre negros e mestiços. Nesse sentido, a ordem social criou uma divisão de forças produtivas. 0 europeu reservou-se ao comércio e à gerência das atividades econômicas e das atividades burocráticas da Igreja e do Estado. A população livre e pobre ocupou setores onde não se explorou a mão-de-obra escrava, como nos ofícios mecânicos, o garimpo e a faiscagem (...) e, mais particularmente no caso dos mestiços, as atividades artísticas (MONTEIRO, 2006, p.60).

A arte sacra produzida nas Minas devia seguir as regras ditadas pela Igreja, trazidas do reino e absorvidas na colônia. No caso das artes plásticas, é possivel se perceber uma transformação por parte de alguns artistas, com santos negros e mulatos, como por exemplo, nas pinturas de Mestre Ataide ${ }^{9}$ na Igreja de São Francisco em Ouro Preto (Ex.1). No caso da arquitetura, nos deparamos com características peculiares, forjadas pelas dificuldades de acesso e recursos locais, resultando na adequação do sistema construtivo aos materiais encontrados no local, como o uso do adobe e da pedra sabão, além da madeira; também a presença de um grande afluxo de pessoas advindas de diferentes regiões, com especial atenção aos portugueses oriundos da região do Minho (RAMOS, 2008), irá ocasionar a absorção de tradições culturais diversas, com importante influência do traço arquitetônico característico da região norte de Portugal (JUNIOR, 1939, p.116), (Ex.2 e 3).

\begin{abstract}
A sede insaciável do ouro estimulou a tantos a deixarem suas terras e a meterem-se por caminhos tão ásperos como são os das minas, que dificultosamente se poderá dar conta do número de pessoas que por lá estão. (...) Das cidades, vilas, recôncavos e sertões do Brasil, vão brancos, pardos e pretos, e muitos índios, de que os paulistas se servem. A mistura é de toda a condição de pessoas: homens e muIheres, moços e velhos, pobres e ricos, nobres e plebeus, seculares e clérigos, e religiosos de diversos institutos, muitos dos quais não têm no Brasil convento nem casa. (ANTONIL, 1982, p.167).
\end{abstract}

No caso da música, podemos observar uma simplificação do que se encontrava na Europa, adequando-se ao ensino não institucionalizado existente (BINDER, 1998, p.212), aos serviços religiosos que aqui aconteciam e ao número de profissionais atuantes (CASTAGNA, [s.d.], p.5-10). De acordo com Dom Oscar de OLIVEIRA ${ }^{10}$ (1984, p.33), tão logo se instalou o bispado em Mariana, em 1749, foi grande o "interesse da Igreja para ensinar os meninos a "ler, escrever e contar". (...) Vez ou outra se acrescenta ensinamento também de música." Com provisões para professores para ensinar a "ler, escrever e solfa".

0 enriquecimento decorrente da mineração irá permitir uma manifestação religiosa com toda a pompa que a sociedade católica em Minas, com as suas irmandades e ordens terceiras, podia exibir.

As confrarias, nascidas dos grandes contrastes sociais, estimulavam as vaidades, despertando a competição entre os confrades das diversas classes sociais. Assim, Irmandades e Ordens Terceiras transformaram-se em organismos promotores de cultura e de arte na região mineira. (BARBOSA, 1978, p.33). 


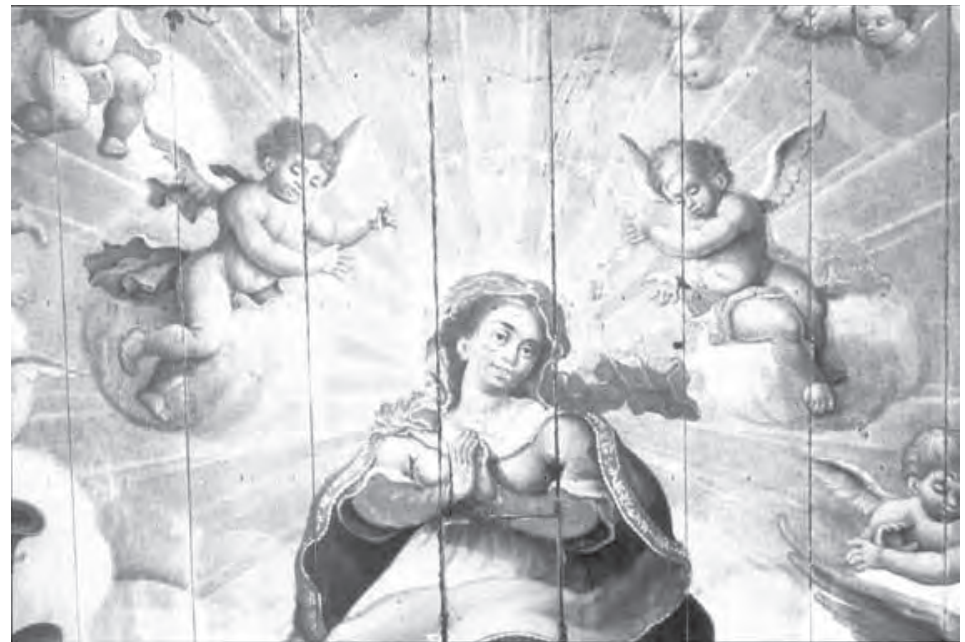

Ex.1 - Detalhe da pintura do forro da nave da Igreja São Francisco de Assis de Ouro Preto

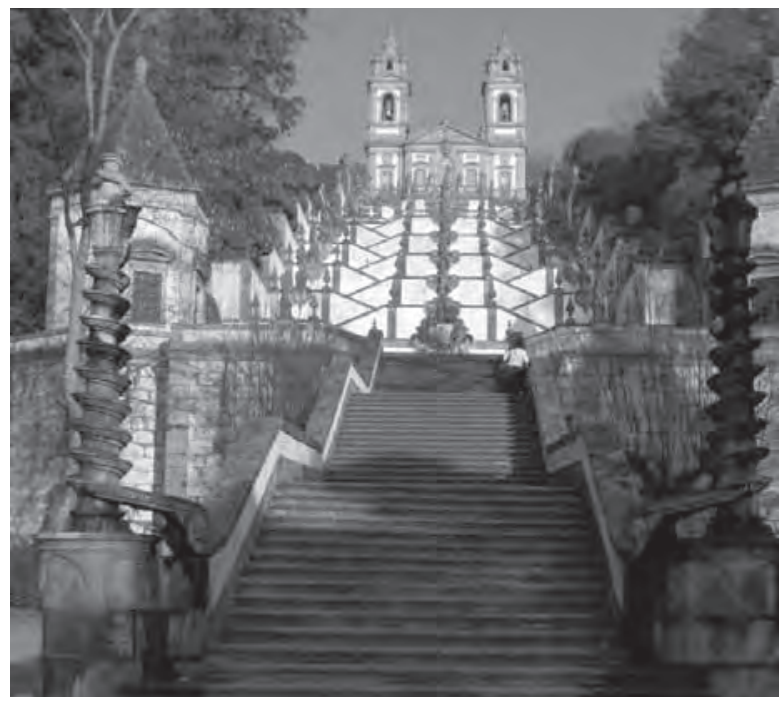

Ex.2 - Santuário do Bom Jesus de Braga, Portugal

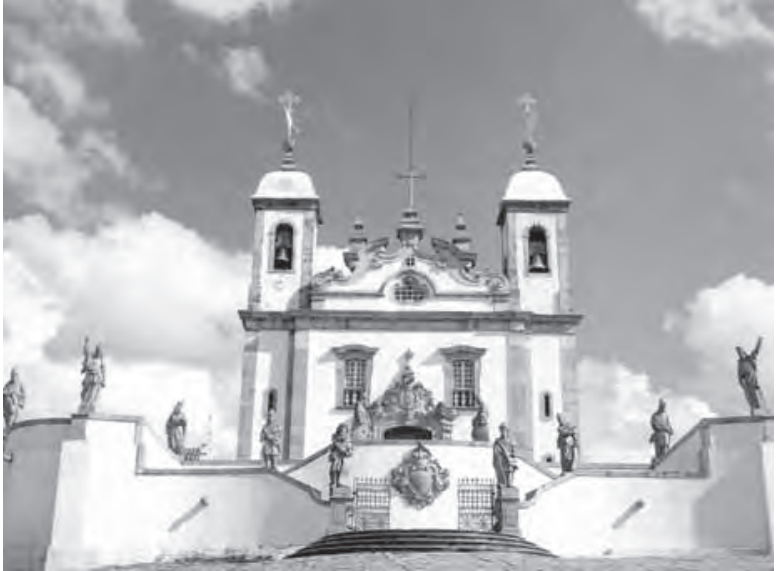

Ex.3 - Igreja do Senhor Bom Jesus de Matozinhos, Congonhas, MG.

As irmandades contratavam um grupo para as suas festas e missas principais, através de um contrato ou ajuste, que era firmado entre o mestre de música responsável pelo grupo e a irmandade. Geralmente estes grupos eram compostos por um coro - constituído por quatro a cinco integrantes, três homens e uma ou duas crianças para a voz de tiple (soprano) - e contínuo ou uma orquestra, constituída geralmente por dois violinos e um baixo nas cordas, e um par de trompas e pares de flautas e/ou oboés (CASTAGNA, [s.d.], p.4-10).

A concorrência entre as irmandades irá impelir os músicos mineiros à criação de música própria e à busca pela atualização em relação aos estilos vigentes na Europa. Segundo Paulo CASTAGNA" ([s.d.], p.6), a grande competição entre as irmandades e a diminuição do ouro, irá provocar alguns fenômenos importantes no meio musical mineiro:

0 primeiro deles foi a proliferação de músicos compositores entre os mulatos, espécie de classe intermediária do período colonial, que se viu forçada a um trabalho intenso para garantir a sobrevivência. 0 segundo foi a necessidade que esses compositores tiveram de dominar mais um estilo, agora o pré-clássico, só que desta vez com uma perícia nunca antes observada no país. Esse estilo, originário da Itália, mas difundido em Portugal a partir do centro do século XVIII, foi rapidamente assimilado em Minas Gerais. Com isso, Portugal passava a ser para os músicos mineiros, apenas um intermediário inevitável entre a Itália e as Américas.

José Joaquim Emerico Lobo de Mesquita, autor da Missa em Mi bemol, objeto de minha pesquisa, atuou na região dos diamantes na segunda metade do século XVIII, como compositor, organista, regente, e professor de música. Como não foi encontrada ainda qualquer prova documental a respeito de sua origem ${ }^{12}$, é considerado nascido na Vila do Príncipe do Serro do Frio (atual Serro), por 
volta de 1746, tendo seu nome citado pela primeira vez no livro de pagamentos da Câmara do Serro, em 26 de dezembro de 1774, referente ao pagamento de quatro festas anuais (LANGE, 1983).

Mudou-se para o Arraial do Tejuco (Diamantina) em 1783, atuando como organista na Igreja de Santo Antonio, constando o registro de seu primeiro pagamento em 1784 (COTTA, 2005, p.24). Lobo de Mesquita viveu em Diamantina em época de intensa riqueza e atividade cultural, coincidindo com o período da Real Extração, no qual o governo Português decidiu explorar por conta própria a terra dos diamantes e não mais realizar arrendamentos, que permitiam fraudes e abusos (SAINT-HILAIRE, 1974, p.14). Segundo relata Júnia Ferreira FURTADO ${ }^{13}$ (2008, p.56) em suas pesquisas sobre o Livro da capa verde ${ }^{14}$, "o período que se inicia com a Real Extração, em 1772, e principalmente o compreendido entre 1775 até 1795 correspondeu ao auge da produção diamantina (...)." Segundo a autora este momento também assistiu ao auge de sua decadência entre os anos de 1800 a 1806, quando Lobo de Mesquita já não se encontrava em Diamantina.

A permanência do compositor na comarca dos Diamantes corresponde à sua atividade profissional mais intensa. Os autógrafos encontrados, todos datados, "além das raras cópias que mencionam o ano de suas composições, dão prova de sua produção entre 1778 e 1803" (COTA, 2005, p.24).

Em 1788, Lobo de Mesquita ingressou na Confraria de Nossa Senhora das Mercês dos Homens Crioulos, onde, alguns meses depois, deu entrada a sua esposa, Tomásia Onofre do Lírio e, em 1793, encontramos o nome de sua escrava, Teresa Ferreira, no livro da irmandade, como prestadora de serviços e irmã (LANGE, 1983, p.140). 0 compositor também aparece como irmão na Irmandade de Nossa Senhora do Amparo em Diamantina - irmandade de mulatos (LANGE, 1983, p.141-143).

Em 1789, com o título de alferes, Lobo de Mesquita aparece no Livro de Termos da Ordem do Carmo de Diamantina, como organista contratado, executando o órgão construído pelo organeiro ${ }^{15}$ local, Pe. Manuel de Almeida Silva, permanecendo até 1795 (PIRES, 2007, p.26). Consta no Livro de Receita e Despeza da Matriz de Santo Antonio - Irmandade do Santíssimo Sacramento - o registro de seu último pagamento como organista em Diamantina, no ano de 1798 (SILVA, 2008, p.66).

No mesmo ano de 1798, mudou-se para Vila Rica (Ouro Preto), assinando contrato com a Ordem Terceira do Car$m o$, se responsabilizando pela música executada na mesma. Também se encarregou da música para a Confraria do Santíssimo Sacramento e de quatro festas promovidas pelo Senado da Câmara em 1799. Permaneceu pouco tempo em Ouro Preto, transferindo-se para o Rio de Janeiro, onde assinou contrato em 1801 com a Ordem Terceira do Carmo, exercendo a função de organista. Faleceu em 1805, no Rio de Janeiro (COTTA, 2005, p.25).

\section{4 - Paralelo entre peças para solo de soprano de Mesquita, Perez e Jommelli}

Para o presente artigo foram escolhidas três obras: o solo de soprano da Missa em Mi bemol de José Joaquim Emerico Lobo de Mesquita, objeto da minha pesquisa; o solo de soprano de uma Missa a cinco vozes, também em Mi bemol, de David Perez; e a primeira ária do Moteto para solo de soprano, Care Deus si respiro, de Niccollò Jommelli.

A escolha das obras seguiu critérios objetivos, em parte, mas também subjetivos: as três são peças de caráter sacro; escolhi peças para solo de soprano, por permitirem o acesso à minha própria voz, possibilitando assim que eu testasse as opções de interpretação fundamentadas na pesquisa; Perez e Jommelli foram compositores italianos que exerceram importante influência na música portuguesa na segunda metade do século XVIII; a obra de Lobo de Mesquita é o fulcro de minha pesquisa; por último, mas não menos importante, era necessário que as três obras fossem facilmente acessiveis para consulta.

Tanto a missa de Lobo de Mesquita quanto a de David Perez, são Missas contendo apenas o Kyrie e o Gloria, trechos que integram o ordinário, ou partes fixas da Missa. 0 Kyrie corresponde ao ato penitencial e o Gloria é o momento de louvor a Deus, intercalado de aclamações e súplicas (VIAGRANDE, 2005, p.13-14). Os dois compositores escrevem no modelo de missa napolitano, no qual o ordinário é fragmentado em formas menores, separado em Arias solo, duetos, concertatos, coros e intervenções instrumentais.

A segmentação em passagens curtas facilita a diversificação do texto do ordinário, indo ao encontro das exigências agógicas e de dinâmica, e das mudanças de atmosfera, permitindo o uso das figuras retórico-musicais mais adequadas às imagens indicadas no texto, ou ao afeto representado por cada momento. No texto do ordinário da missa, há momentos episódicos, como o Gloria e o Credo, nos quais é possível interromper o discurso musical para melhor caracterizá-lo, e momentos mais diretos, concisos e similares em sua formulação, como o Kyrie e o Agnus Dei (GARBINI, 2005, p. 295).

Também o moteto, vem interpretado por meio de articulações do texto, criando uma sucessão de momentos musicais contrastantes. Encontramos no dicionário eletrônico de italiano GARZANTI (2006), três significados para a palavra motetto, composição poética constituída de poucos versos em rima, de caráter popular e brilhante; forma sacra polifônica vocal ou vocal-instrumental que se desenvolve a partir do século XIII; diminutivo de motto (dito, ditado, palavra, epígrafe).

0 moteto era inicialmente uma obra contínua polifônica (stilo antico), Claudio Monteverdi ${ }^{16}$, importante compositor italiano do início do período barroco, passou a segmentá-lo com o objetivo de descrever melhor o sentido do texto e seus afetos (ARNOLD, 2009). 
Os compositores que atuaram nos conservatórios femininos venezianos e napolitanos tinham o hábito de escrever motetos marianos ${ }^{17}$ para as suas alunas, em alguns casos, com dedicatória dirigida a alguma aluna em especial. Jommelli atuou no Conservatório Incurabili em Veneza, escrevendo vários motetos a partir de 1750 (ARNOLD, 2009).

A maioria dos compositores napolitanos que trabalharam em Veneza, nessa época, eram compositores de ópera, refletindo a influência deste gênero em seus motetos. 0 padrão do moteto era de quatro movimentos: uma ária, um recitativo, outra ária e um brilhante alleluia. Este é o caso do moteto em questão.

Para a análise do solo de soprano de Lobo de Mesquita, foram utilizados os manuscritos pertencentes ao Museu da Música de Mariana (MMM). São manuscritos nãoautógrafos, da cidade de Barra Longa, Minas Gerais, alguns com data de 1864, outros sem data e um datado de 1871. Uma das fontes está praticamente completa, com a instrumentação de soprano, tenor, baixo, primeiro e segundo violino, baixo instrumental, primeiro e segundo oboé e primeira e segunda trompa, faltando apenas a voz de contralto, que pertence a uma segunda fonte incluída neste conjunto de manuscritos de Mariana. Foram também consultados, em um segundo momento, os manuscritos pertencentes ao Museu da Inconfidência em Ouro Preto (MIOP).

Nos manuscritos de Mariana temos duas fontes com 0 solo de soprano Quoniam da Missa em mi bemol. Em uma das fontes, ele aparece inserido na parte de tenor antecedido pelos dizeres Sperciso a Solo, hé o q.' se segue ade.,18 podendo significar uma não obrigatoriedade na execução do mesmo. Apesar de estar escrito na parte com a clave de tenor (clave de dó na quarta linha), foi copiado como se a clave estivesse na primeira linha (clave de soprano), com um único sustenido no segundo espaço (o solo está na tonalidade de sol maior), configurando um sol sustenido, obviamente um engano do copista, que realiza posteriormente uma rasura para correção do erro, modificando a clave, neste movimento, para clave de dó na primeira linha (Ex.4 e 5). Possivelmente por não possuírem no momento da montagem da obra, um homem sopranista ou tiple (menino soprano) capaz de executar o solo, este foi transferido para o tenor.

No conjunto de partes, encontramos uma segunda fonte contendo apenas o solo de soprano, com a palavra carti-

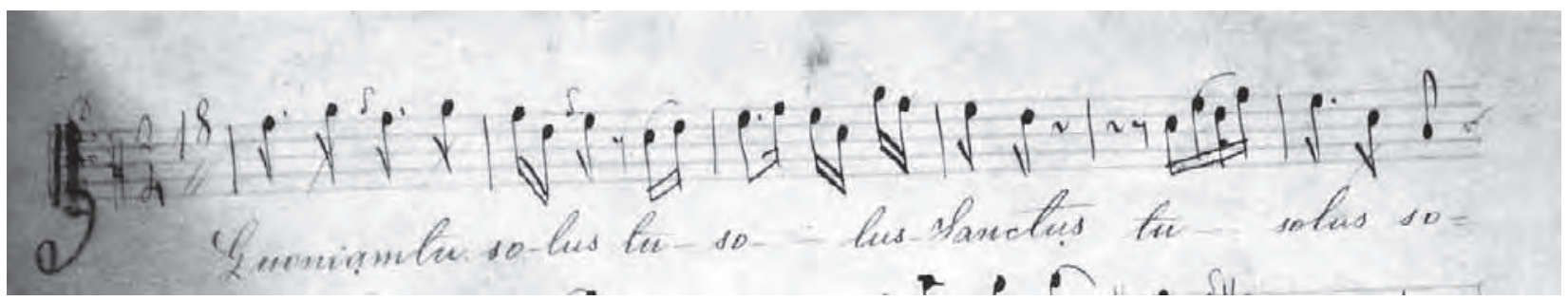

Ex.4 - Cópia do solo de soprano inserida na parte de tenor (MMM).

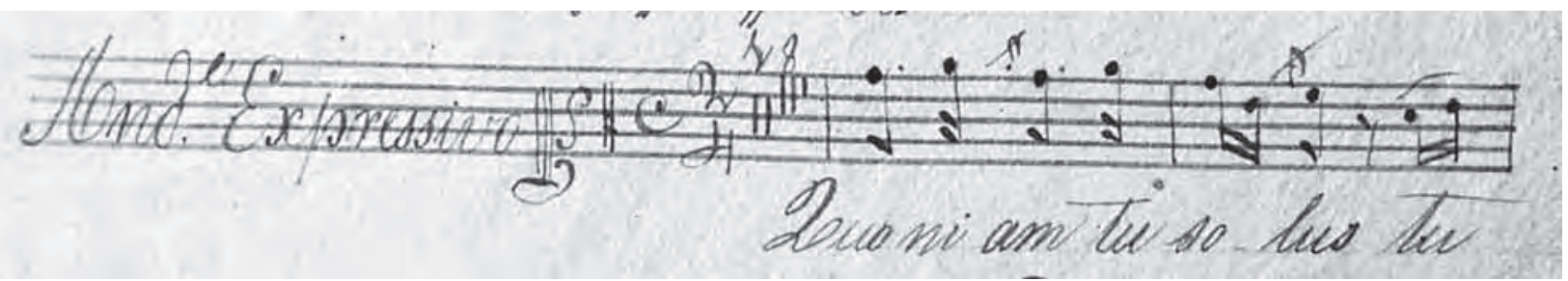

Ex.5 - Solo de soprano do manuscrito de Ouro Preto (MIOP)

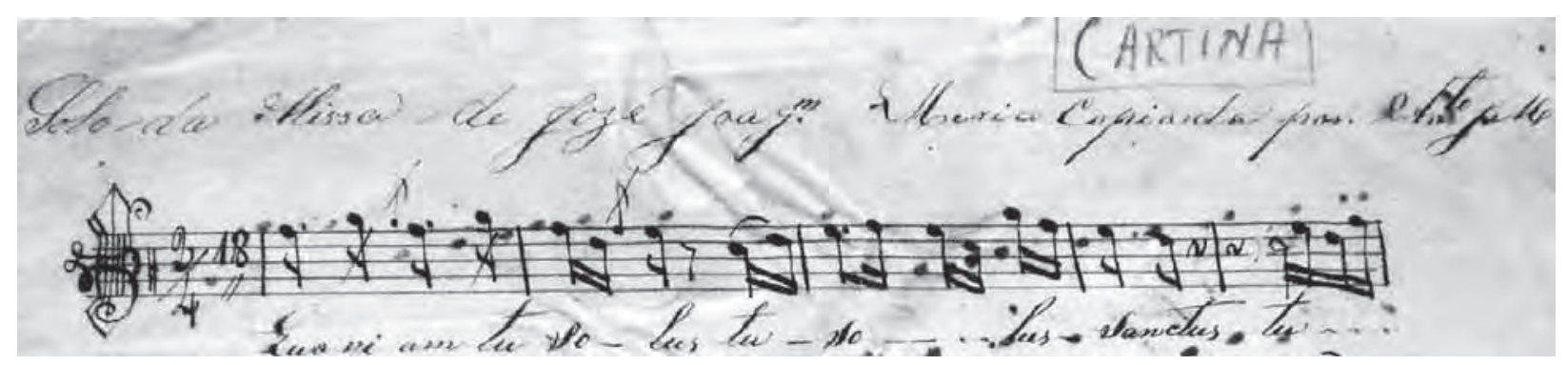

Ex.6 - Cópia do solo de soprano utilizando a clave de contralto (MMM) 
$n a^{19}$ escrita na parte superior, em letra diferente da do copista e em caixa alta, também indicando uma não-obrigatoriedade na execução do solo. Esta parte está escrita na clave de dó na terceira linha (clave de contralto), com um único sustenido que, pela posição da clave, significaria a nota si sustenido, configurando novamente um erro por parte do copista (Ex.6).

0 manuscrito referente ao baixo instrumental não possui cifras. Considerando-se que Lobo de Mesquita era organista, provavelmente elas deveriam existir em seus originais, como se pode observar em suas partituras autógrafas (vide fac-símile do manuscrito autógrafo da obra Tercio) (COTTA, 2005, p.195-209). É possivel que a ausência de órgãos na maioria das Igrejas mineiras no século XIX, tenha contribuído para o abandono das cifras por parte dos copistas oitocentistas.

É importante observar que nos manuscritos da missa de Lobo de Mesquita, cada parte vocal possui o seu solo inserido na parte de coro. Tal fato pode indicar que apenas um cantor realizava cada voz, o que concorda com os documentos compilados por Curt LANGE (1983, p.35-44) que apontam para conjuntos com uma a duas vozes de tiple, um alto, um tenor e um baixo, apenas com vozes masculinas, e um instrumento de cada.

Para o estudo da obra de Perez, foram empregados manuscritos encontrados no site Internet culturale. São cópias manuscritas não-autógrafas, [s. d.], que incluem apenas o Kyrie e o Gloria, com a seguinte instrumentação: soprano I e II, alto, tenor, baixo, violinos I e II, violoncelo, contrabaixo, oboés I e II e Órgão. Nestes manuscritos encontramos primeiramente o solo de soprano acompanhado de contínuo, sucedendo-se as partes de coro, com as partes do quarteto solista discriminadas separadamente. Finalmente, as partes instrumentais, com cópias dobradas para os violinos I, II e violoncelo, indicando um conjunto vocal e instrumental bem maior do que o disponível em Minas Gerais.
A obra de Jommelli foi retirada do site Choral Wiki e seus manuscritos originais se encontram no Civico $\mathrm{Mu}$ seo Bibliografico Musicale di Bologna. (Jommelli, 2008). A obra está escrita para voz de soprano (provavelmente voz feminina) e os instrumentos são violinos I, II e baixo contínuo. Para o presente artigo utilizaremos apenas 0 primeiro movimento.

A ária Care Deus si respiro, de Jommelli, está em compasso quaternário, no andamento Allegro e na tonalidade de dó menor, a "das coisas maravilhosas, mas com certa tristeza", segundo Johannes Mattheson, compositor e teórico alemão, ou "dos assuntos ternos e melancólicos", como diz Jean-Philippe Rameau, compositor e teórico francês (CYR, 1998, p.32). É a obra com a utilização de uma maior extensão vocal dentre as três, tendo sido provavelmente escrita quando Jommelli lecionava música para as meninas do Conservatório Incurabili, em Veneza.

A missa de Perez, assim como a de Lobo de Mesquita, está escrita em Mi bemol, a "tonalidade das coisas sacras", com os três bemóis representando a santíssima trindade, de acordo com Mattheson (RÓNAI, 2009). Já o Gloria de Lobo de Mesquita está na tonalidade de Dó maior, "o tom apropriado para as canções de alegria e júbilo", segundo JeanPhilippe Rameau. (CYR, 1998, p.32). 0 Gloria da missa de Perez está escrito em Ré maior e o solo de soprano (Qui sedes) está na tonalidade de Sol maior, "a tonalidade das coisas sérias e alegres" segundo Mattheson (CYR, 1998, p. 33). Também na tonalidade de Sol maior está o solo da missa de Lobo de Mesquita, para as frases do Quoniam, trecho onde o texto exalta o Senhor. Para o solo de soprano, ambos utilizam apenas as cordas como acompanhamento.

A melodia nas três obras se apresenta com frases curtas e periódicas, sendo expressiva e enfatizando o texto. 0 procedimento de valorização e descrição das palavras ou

\begin{tabular}{|c|c|c|c|}
\hline & $\begin{array}{c}\text { Quoniam } \\
\text { Lobo de Mesquita } \\
\text { Sol maior } \\
\text { Andante espressivo, 2/4 }\end{array}$ & $\begin{array}{c}\text { Qui sedes } \\
\text { David Perez } \\
\text { Sol maior } \\
\text { Andantino, 4/4 }\end{array}$ & $\begin{array}{c}\text { Care Deus } \\
\text { Niccolò Jommelli } \\
\text { Dó menor } \\
\text { Allegro, } 4 / 4\end{array}$ \\
\hline Texto original & $\begin{array}{l}\text { Quoniam tu solus Sanctus, } \\
\text { Tu solus Dominus, } \\
\text { Tu solus Altissimus Jesu } \\
\text { Christe }\end{array}$ & $\begin{array}{l}\text { Qui sedes ad dexteram } \\
\text { Patris } \\
\text { Misere nobis }\end{array}$ & $\begin{array}{l}\text { Care Deus, si respiro, per te } \\
\text { vivo, per te spiro, vivo per } \\
\text { te. } \\
\text { Unguetorum me tuorum, in } \\
\text { odorem per amorem fac me } \\
\text { currere pro te. }\end{array}$ \\
\hline Tradução & $\begin{array}{l}\text { Por que só vós dois Santo, } \\
\text { Só vós sois Senhor, } \\
\text { Só vós sois o Altíssimo } \\
\text { Jesus Cristo }\end{array}$ & $\begin{array}{l}\text { Aquele que está sentado à } \\
\text { direita do Pai, } \\
\text { Tende piedade de nós. }\end{array}$ & $\begin{array}{l}\text { Caro Deus, sim respiro. Por ti } \\
\text { vivo, por ti respiro, vivo por } \\
\text { ti. } \\
\text { Tu és o meu bálsamo, } \\
\text { através do perfume pelo } \\
\text { amor, me guie até Vós. }\end{array}$ \\
\hline
\end{tabular}

Ex.7 - Letras das músicas e respectivas traduções. 
afetos através de recursos composicionais (word painting) está presente nas três obras. Seguem abaixo os textos das músicas com suas respectivas traduções (Ex.7).

As obras possuem ornamentação inserida na linha melódica, além da indicação da ornamentação em notação pequena. A melodia na obra de Lobo de Mesquita é predominantemente diatônica, com alguns cromatismos que realçam o afeto do texto, principalmente na segunda parte, tu solus altissimus, Jesu Christe, enfatizando a reverência a Deus. Jommelli e Perez utilizam intensamente o cromatismo em suas obras, que possuem uma harmonia mais arrojada, ritmo harmônico mais movido com pouca utilização de progressões harmônicas. As obras de Perez e Lobo de Mesquita utilizam praticamente a mesma extensão vocal e uma tessitura mais central (Ex.8).

Lobo de Mesquita escreve o Quoniam com um acompanhamento de cordas em textura homofônica. Na introdução, o primeiro violino realiza a melodia, acompanhado pelo contínuo e pelo segundo violino, que segue em semicolcheias, executando notas do acorde. Com a entrada da voz, o primeiro violino mantém a melodia em dobramento durante quase toda a peça. Em alguns momentos, pequenos diálogos entre a voz e o primeiro violino acontecem. Na peça há a predominância de um acompanhamento simples, que destaca a melodia principal, fio condutor da música. Primeiro e segundo violinos só caminham em terças nos momentos de transição entre as seções e na finalização da obra. 0 baixo é simples, provavelmente como consequência da adoção de um ritmo harmônico mais lento, "tendências pós-barrocas que concedem à harmonia um papel de segundo plano à melodia, atribuindo-Ihe como função primordial tornar esta última mais clara e perceptível." (FERNANDES, 2005, p.193) (Ex.9).

0 Quoniam inicia com uma introdução instrumental (Ai) na região de sol maior. Com a entrada da voz, se seguem três seções (A1, A2 e A3) onde o mesmo texto é apresentado. A primeira parte do texto está sempre em sol maior. Na segunda parte, tu solus Altíssimus, Jesu Christe, Lobo de Mesquita realiza procedimentos tais como, deslocamentos do centro tonal, criando novos coloridos, emprego de coloraturas sobre a palavra Jesu, utilização de cromatismos e saltos ascendentes sobre a palavra Altissimus, (procedimento de pintura de palavras). Na segunda parte do texto da seção A2 a harmonia caminha para o VI grau, dando nova ênfase à sua melodia. Na seção A3 a harmonia se mantém estável na tonalidade principal, mas em contrapartida, o compositor realiza o ponto culminante do Quoniam, agregando força à melodia (Ex.10).

\begin{tabular}{|c|c|c|}
\hline Quoniam & $\begin{array}{c}\text { Qui sedes } \\
\text { Lobo de Mesquita }\end{array}$ & $\begin{array}{c}\text { Care Deus si respiro } \\
\text { Niccoló Jommelli }\end{array}$ \\
\hline
\end{tabular}

Ex.8 - Extensão vocal.

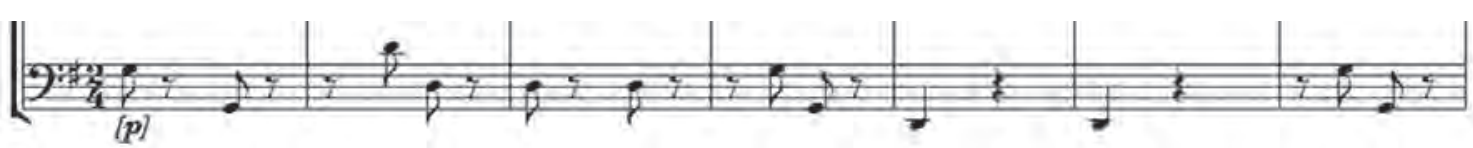

Ex.9 - Trecho do baixo do Quoniam de Lobo de Mesquita.

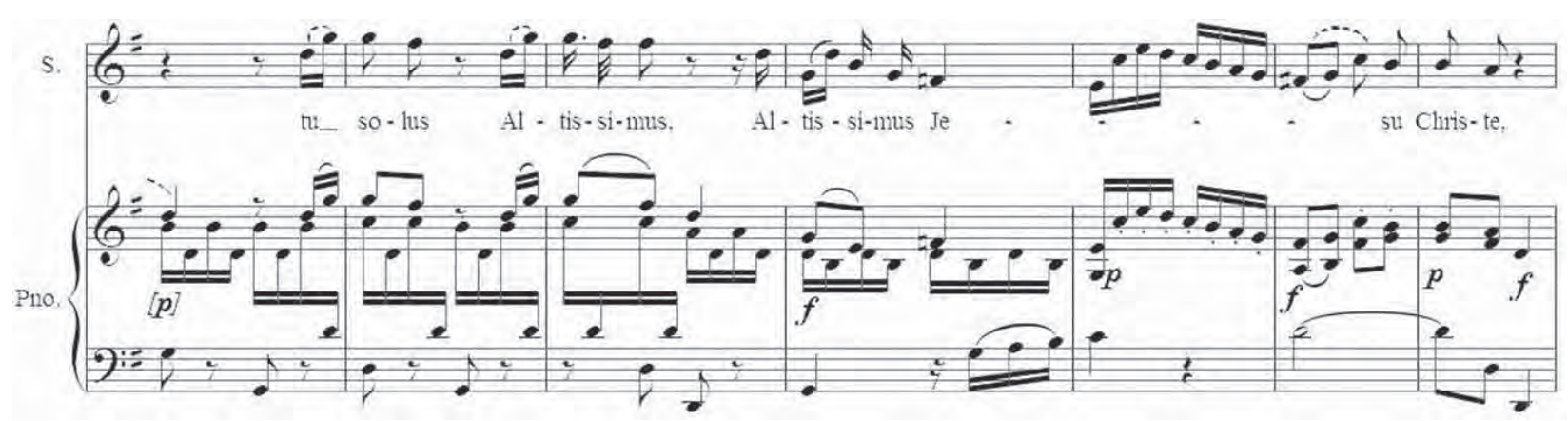

Ex.10 - Procedimentos melódicos de valorização do texto e ponto culminante. 
Lobo de Mesquita realiza um procedimento semelhante ao da ária da $\operatorname{capo}^{20}$, na qual a seção B está representada pela seção $A 2$, iniciando na região da Tônica, atingindo posteriormente a região do sexto grau (Ex.11)

A obra de Perez possui, como as outras, uma introdução instrumental onde o material temático que será cantado pela voz já se apresenta. No c.5, o compositor introduz uma pausa de semibreve para todos os instrumentos, criando um momento de suspensão e produzindo uma atmosfera quase operística. É importante lembrar que até a sua chegada a Portugal, Perez apenas havia escrito óperas, sendo considerado em seu tempo como um grande compositor do estilo. Somente em Portugal, com a contingência do terremoto, passa a escrever para a capela real (Ex.12).

Perez divide o texto em duas partes, assim como Lobo de Mesquita, mas trabalhando dois materiais temáticos diferentes para cada trecho. 0 material temático da primeira parte do texto aparece sempre na tonalidade principal (Sol Maior) e é quase silábico. Sobre o segundo trecho do texto, miserere nobis, irá primeiramente trabalhar na região da dominante (Ré Maior), utilizando coloraturas e enfatizando a palavra miserere. Na segunda repetição, a peça inicia na região do segundo grau (Lá menor), passa pelo VI grau, chega à dominante preparando para voltar à tonalidade de Sol Maior (I). 0 compositor emprega coloraturas, com um ritmo harmônico bastante intenso, procedimento bem barroco, apesar de sua melodia já ser periódica, de certa forma bi-temática, e não utilizar a forma da capo. Como Lobo de Mesquita, Perez repete o texto completo por três vezes, mas a sua terceira seção possui um caráter de coda, em que são recapitulados os elementos utilizados e afirmando a tonalidade (Ex.13). Apesar de ser a melodia mais rica em coloraturas dentre as três obras, é a que possui a tessitura mais central.

$\mathrm{Na}$ introdução do Qui sedes, os violinos se apresentam ora em estilo concertato ${ }^{21}$, ora em uníssono. Nas outras seções, os violinos caminham às vezes em uníssono, alguns momentos em terças ou quartas, ou realizam alguns poucos diálogos entre si. Das três obras, a de Perez é a que possui a instrumentação mais densa nos baixos, com duas cópias para violoncelo no conjunto de manuscritos, além da utilização do contrabaixo e do órgão. 0 violino realiza dobramentos com a voz, mas menos intensamente do que nas obras de Lobo de Mesquita e Jommelli. A linha vocal em sua obra é a que possui uma maior independência, com momentos de acompanhamento bem harmônico e até trechos a capella. 0 compositor utiliza de todos os

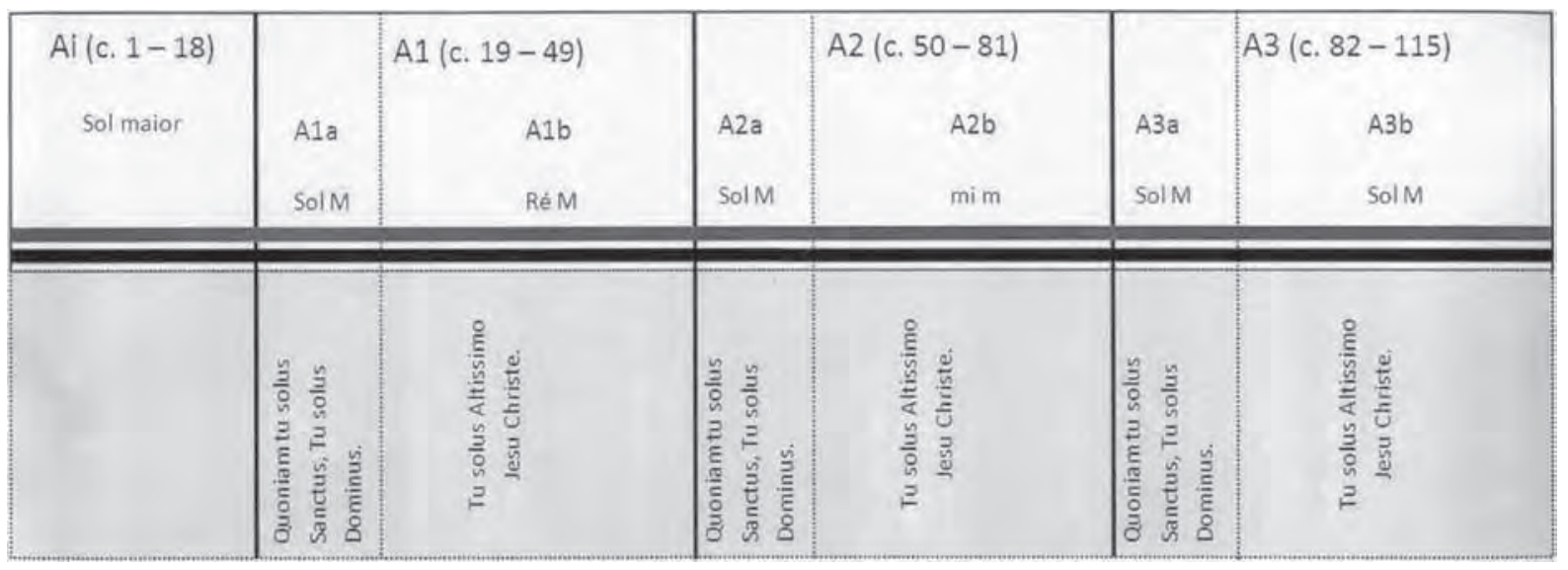

Ex.11 - Forma do Quoniam da Missa em Mi bemol de Lobo de Mesquita.

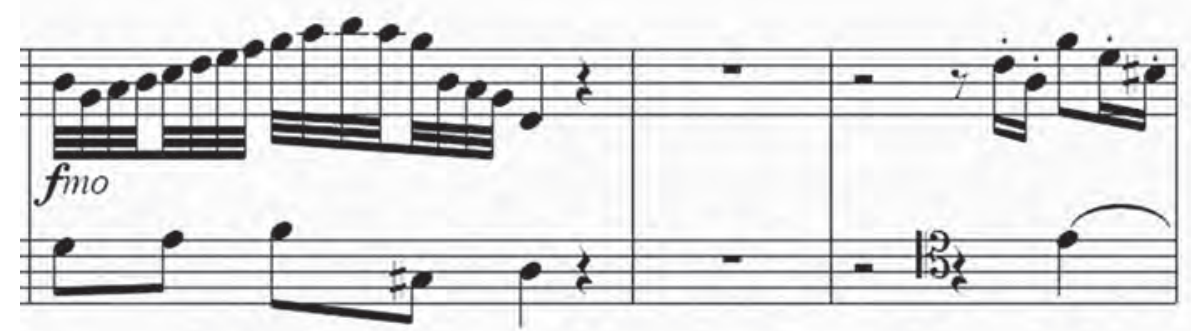

Ex.12 - Momento de suspensão na introdução do Qui sedes de Perez 


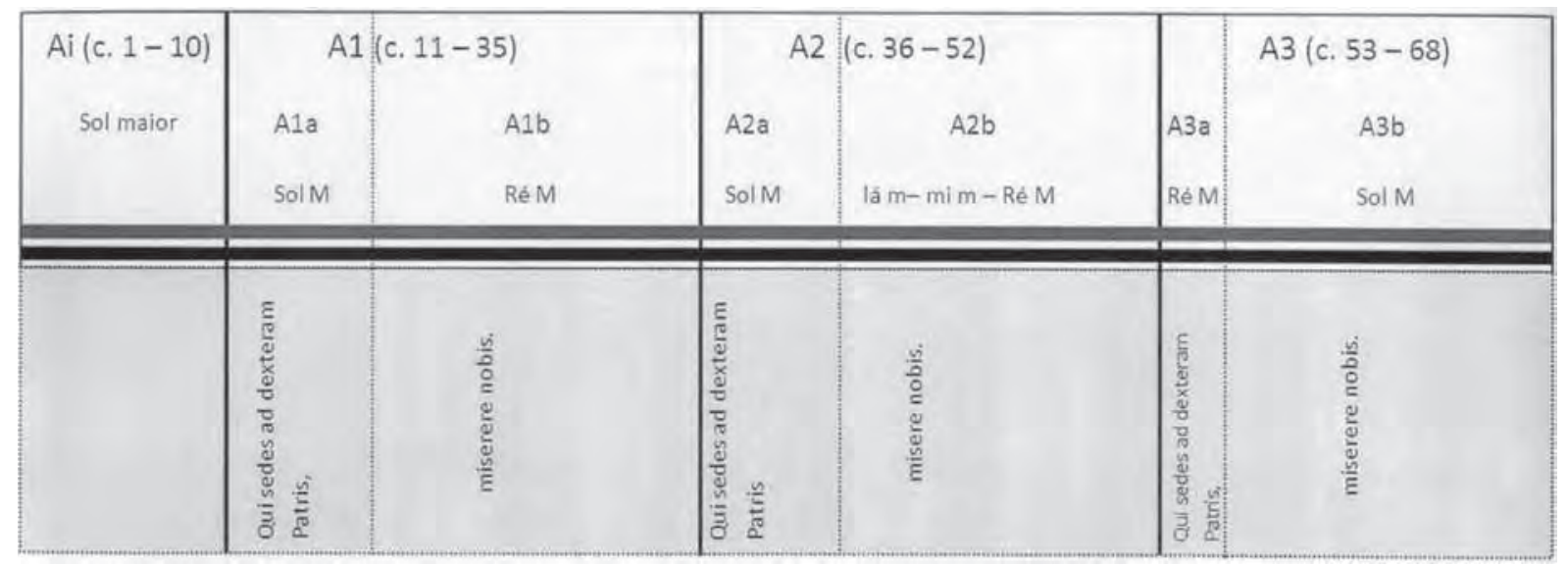

Ex.13 - Forma do Qui sedes da Missa a cinco vozes de David Perez.

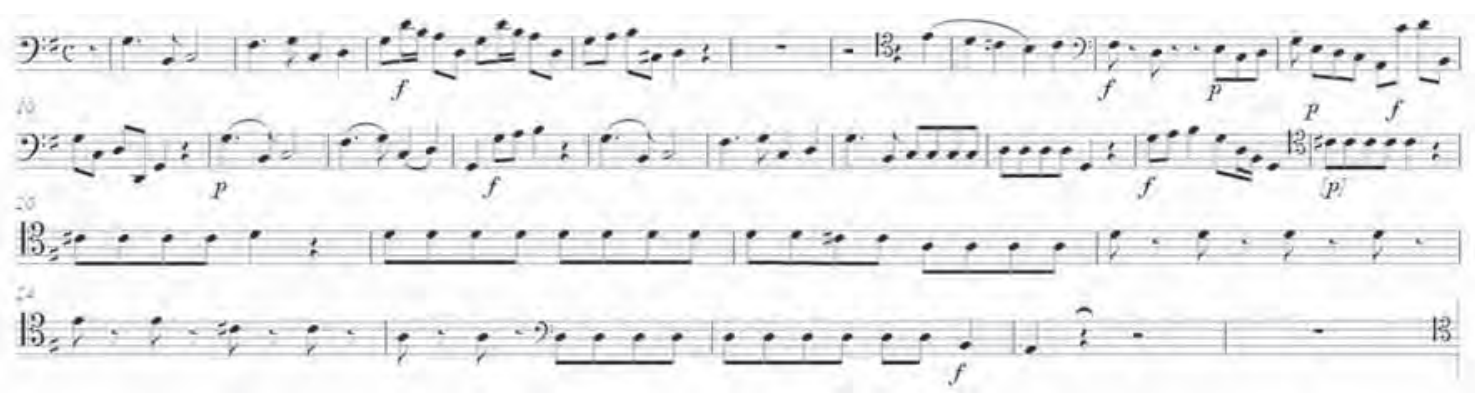

Ex.14 - Baixo do Qui sedes de Perez.

recursos composicionais, com seções homofônicas, contrapontísticas, a capella e até momentos de interrupção total da música, criando várias atmosferas e contrastes. 0 baixo alterna entre momentos de uma construção melódica mais elaborada, caracterizando uma linha melódica independente, para momentos com notas repetidas de caráter percussivo (trommelbass) (Ex.14).

A peça de Jommelli esta na forma de ária da capo. 0 compositor também apresenta o material temático que será apresentado pela voz em sua introdução, que está na tonalidade principal, dó menor. Na ária da capo o texto é dividido em duas partes, uma para a seção A e outra para a seção B. Como Perez e Lobo de Mesquita, ele divide cada subseção do texto em duas partes, trabalhando dentro da seção $A$ com duas partes de texto. Apresenta a primeira parte do texto A, Care Deus si respiro, na tonalidade de Dó menor e caminha para a tonalidade de Mi bemol maior (tonalidade relativa) onde trabalha a segunda parte do texto da seção A. Como Perez e Lobo de Mesquita, Jommelli apresenta o texto da seção A por três vezes. Na segunda e na terceira vez, de forma diversa aos outros dois, teremos a primeira parte do texto na tonalidade de Mi bemol, retomando a tonalidade de Dó menor apenas no final da grande seção $A$ da ária. Na seção $B$, Jommelli apresenta o texto completo apenas uma vez, predominando a tonalidade de Mi bemol maior, repete partes do texto na região de Sol menor, já se preparando para retomar o tom de Dó menor na repetição da ária da capo (Ex.15).

Durante quase toda a introdução da obra de Jommelli, os violinos se apresentam em uníssono, com apenas dois compassos onde caminham em terças. 0 primeiro violino dobra a voz durante quase toda a peça, com alguns momentos onde dialoga ora com a voz, ora com o segundo violino (concertato). 0 baixo de sua peça é o mais elaborado melodicamente dentre as três obras, ainda com características do baixo continuo barroco (Ex.16).

Jommelli também realiza procedimentos de pintura de palavras, como o uso de pausas entrecortando a palavra respiro, criando a sensação de perda de ar, ou o uso de escalas sobre o texto me currere pro te (me guie até vós), criando o sentido de direcionamento (Ex.17). Tanto Jommelli quanto Lobo de Mesquita fazem grande uso de terminações femininas.

\section{5 - Sugestões de interpretação vocal}

A primeira questão importante é a adequação do canto ao estilo e ao ambiente no qual o cantor se apresenta. Nos tratados de Pier Francesco Tosi e Giambattista Mancini, castrati dos períodos barroco e clássico, ambos se preocupam com o ajuste da intensidade sonora ao local e à ocasião (TOSI, 2002, p.28-29). MANCINI (1912, 


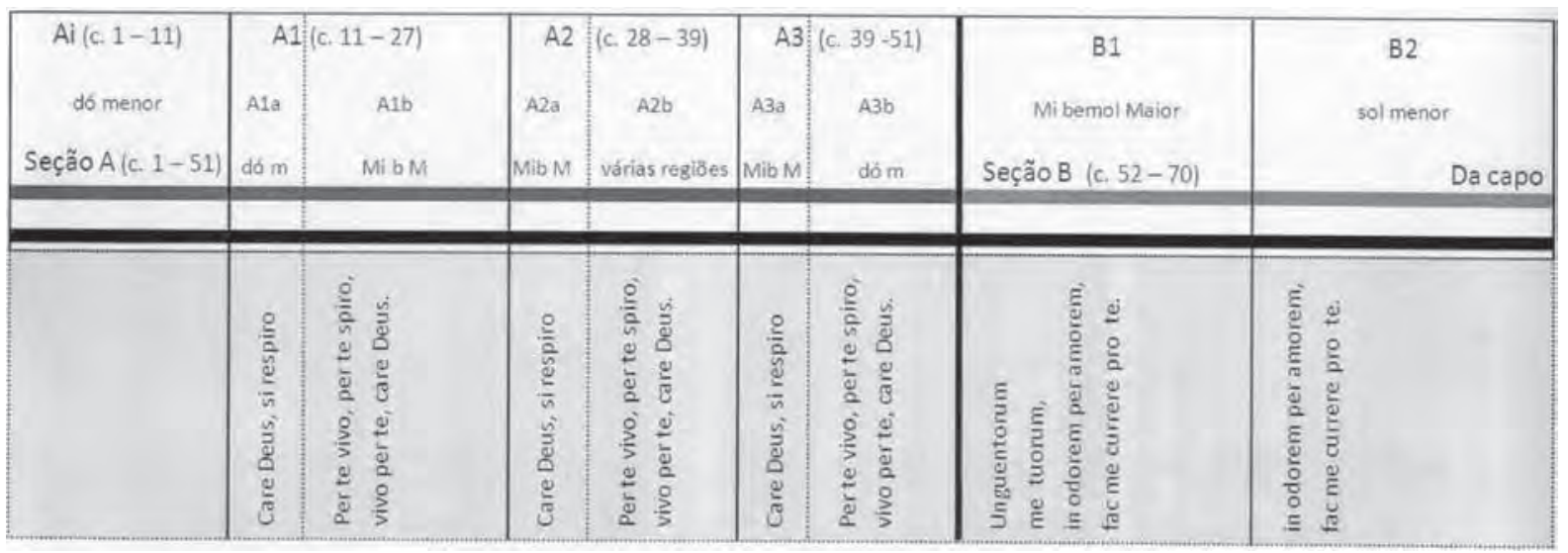

Ex.15 - Forma da ária do moteto Care Deus si respiro de Jommelli.

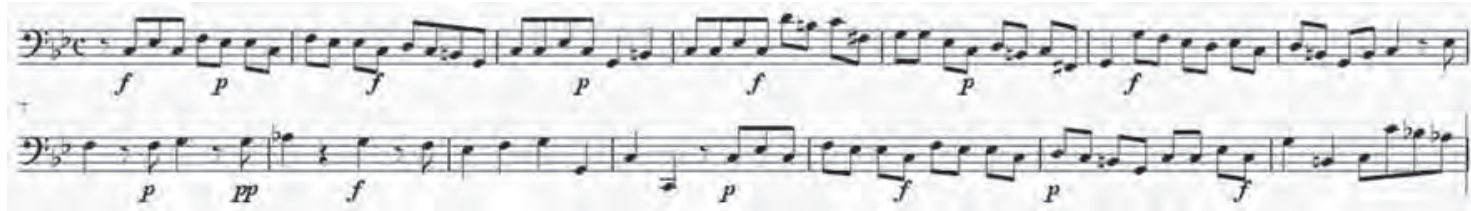

Ex.16 - Trecho do baixo do Care Deus de Jommelli.

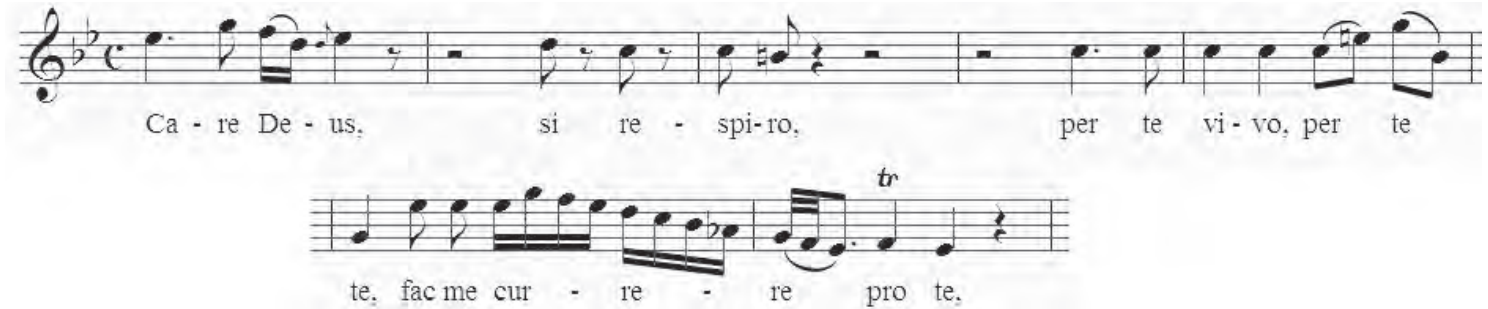

Ex.17 - Exemplos de procedimentos de pintura de palavras em Jommelli.

p.100-101) ainda defende o desenvolvimento da flexibilidade das vozes, permitindo às vozes pequenas uma emissão potente e às vozes grandes, a capacidade de suavizar e purificar a voz. TOSI (2002, p.28-29) destaca a diferenciação entre três estilos, o estilo sacro: grave e afetuoso; o estilo operístico: vivo e variado; e o de câmara: delicado e refinado.

Neste artigo foram analisadas três obras sacras. Nas árias sacras deve-se cuidar para evitar o excesso de ornamentação, inclusive porque as árias aqui apresentadas já possuem alguma ornamentação indicada.

A afinação é outro parâmetro evidenciado pelos tratadistas, diferenciando os semitons menores, formados por sustenidos, e os maiores, por bemóis (MANCINI, 1912, p.70-71). Johann Adam HILLER (2001, p. 53), professor de canto e compositor alemão, observa que os sustenidos devem ser cantados mais acentuados ou duros, enquanto os bemóis devem ser mais leves ou suaves (moles).

É recorrente a preocupação com a dicção do texto por parte dos tratadistas de canto, sugerindo uma pronúncia clara, com a indicação da abertura da boca na posição de um leve sorriso, "clareando a voz ao ponto que a arte ensina", permitindo que se tire maior vantagem das "qualidades naturais da voz" (MANCINI, 1912, p.93-95). Estes procedimentos nos indicam um resultado sonoro mais claro e leve, diferente do resultado sonoro empregado no período romântico e desenvolvido por Manuel Patricio 
Rodríguez GARCIA ( [s.d.], p.13), importante professor e teórico de canto do século XIX, no qual a laringe toma um posicionamento mais abaixado, resultando em produção vocal mais pesada e escura.

Deve-se valorizar as palavras-chave do texto através de mudanças de dinâmica, colorido da voz, acentuação, buscando sempre a expressividade apropriada ao afeto proposto pelo texto. QUANTZ (1966, p.256) instrui a realizar as dissonâncias em uma dinâmica mais forte do que as consonâncias.

No que diz respeito à ornamentação, é possivel realizar trilos, apojaturas, messa di voce ${ }^{22}$, portamentos, mordentes, etc., buscando realçar determinado trecho, ou palavra, ou ainda, afeto. $\mathrm{Na}$ ária da capo deve-se realizar pequenas ornamentações na seção $A$, apresentar alguns poucos ornamentos na seção $B$, e acrescentar outros novos e mais elaborados na repetição da seção A (TOSI, 2002, p.42). As obras aqui focalizadas já apresentam alguma ornamentação escrita, mas ainda assim é possível acrescentar algo novo, até mesmo uma variação rítmica, mas sempre respeitando o estilo.

A apojatura é chamada apojo no compendio de PEDROSO (1751, p.9), que explica a sua execução da seguinte maneira, "(...) o valor se tira da figura que se põe diante dos tais Apojos, e o mais ordinário vem a ser que quando é um apoio somente, se lhe dá a metade do valor que tem a figura seguinte". Se a figura que vem diante da apojatura tiver ponto, então "se há de dar o valor da Figura ao Apojo, e a Figura fica somente com o valor do pontinho". MANCINI (1912, p. 115) recomenda não utilizar a apojatura em palavras que expressem sentimentos fortes, como a raiva, considerando-as apropriadas às cantilenas e aos afetos mais amenos.

Grande atenção é dada pelos tratadistas em relação à cadência, considerada por MANCINI (1912, p.143) "uma das coisas mais difíceis na verdadeira música vocal". TOSI (2002, p.51-61) aconselha a não se fazer todas as cadências longas e iguais, permitindo-se maior liberdade apenas na cadência final, mas sempre respeitando o estilo da obra em questão. 0 tratadista ainda acrescenta a importância da colocação da apojatura final sempre na sílaba forte. PEDROSO $(1752$, p.12) afirma que não se deve respirar no meio da cadência, mas apenas anteriormente ao trinado que prepara o seu final. 0 autor acrescenta que as cadências nunca devem ser feitas sobre as vogais $u$ e $i$. MANCINI (1912, p.144) ressalta ainda que a melodia da cadência deve estar em concordância com o sentimento da obra.

0 vibrato é sempre uma questão polêmica. Nos tratados de Tosi e Mancini, o termo vibrato não é utilizado, existem referências apenas ao trilo e ao mordente. TOSI (1986, p.17) comenta a necessidade de o aluno aprender a sustentar a voz para não desenvolver uma "flutuação desagradável" do som. HILLER (2001, p.99) e PEDROSO (1752, p.11) mencionam a utilização de um tremor na voz (bebung no tratado de Hiller e Tremullo ou Tremido em Pedroso), que pode ser utilizado em notas longas, atacando-se a nota de forma lisa e introduzindo uma flutuação na voz. PEDROSO (1752, p.11) acrescenta que este ornamento pode ser utilizado nas mesmas situações em que se usa o trinado, exceto no final das cadências, onde "infalivelmente há de se ter o Trinado".

\section{Segundo Robert Mason}

0 sinergismo funcional dos músculos opostos é responsável pelo vibrato, e é um fenômeno fisiológico bastante básico" (Mason 1971) Se o vibrato é o resultado da periodicidade natural dos músculos vocais sob um intenso esforço muscular, parece razoável presumir que o vibrato estava presente no canto antigo proporcionalmente à presença deste esforço. [...] Na medida em que os compositores de ópera aumentam o tamanho e a potência das orquestras, e os teatros de ópera aumentam sua dimensão, as vozes necessitam maior potência vocal. A potência vocal necessária era presumivelmente ganha através do aumento da pressão do ar, o que torna também necessário um aumento na resistência glotal e concomitante abaixamento da laringe, submetendo todos os músculos envolvidos no canto a uma grande pressão e levando a um vibrato mais pronunciado. Não é nenhum acidente o fato das discussões sobre o vibrato se intensificarem no final do século XIX e no início do XX, com as óperas de Verdi, Wagner e com os compositores veristas demandando grande potência vocal dos cantores. Com o aumento da potência da voz, as coloraturas foram frequentemente sacrificadas, e o vibrato se tornou mais evidente (STARK, 2008, p.151).

0 andamento na música não era um vetor absoluto, mas algo que se relacionava ao espírito ou expressão relativa à música, ao seu afeto ou paixão. No presente artigo, apresentamos peças sacras em andamento Andante expressivo, Andantino e Allegro. Considerando-se os conselhos de QUANTZ (1966, p.124-126), indicando que o músico deve guiar-se pelo texto, tonalidade, caráter da peça, intervalos e ritmos utilizados para definir o andamento adequado, não apontarei um andamento preciso para cada peça. QUANTZ (1966, p.287) acrescenta ainda que as peças sacras devem ser tocadas em um tempo mais moderado do que no estilo operístico e ensina um método para o cálculo do andamento baseado nos batimentos cardíacos de uma pessoa normal (1966, p.284-287). Deve-se observar que a frequência dos batimentos cardíacos de uma pessoa normal, varia de 60 a 96 (SOCIEDADE BRASILEIRA DE CARDIOLOGIA, 2009). Também salientamos que o ritmo de vida no passado, anteriormente à revolução industrial, seguia a passos bem mais lentos do que o atual.

Os tratadistas de canto observam que a articulação é a consequência de uma boa entonação e entendimento do texto. HILLER (2001, p.67-68) considera três acentos possíveis; os gramaticais, que diferenciam as silabas longas e curtas; os oratórios, que valorizam o significado da palavra; e os patéticos, que valorizam as emoções.

\section{6 - Considerações finais}

Com a análise das obras pudemos observar o conhecimento do sistema composicional europeu por parte de Lobo de Mesquita, cuja música apresenta várias características da música pré-clássica europeia. É música delicada, bem 
elaborada e singela, com a clara preocupação com a valorização do texto, se baseando em um material harmônico simples, condizente com as condições de ensino e transmissão da música nas Minas Gerais do século XVIII. Tal constatação nos permite fundamentar a interpretação da música sacra mineira da segunda metade do século XVIII em tratados europeus de música e de canto, tendo Lobo de Mesquita como um de seus grandes representantes.

A interpretação embasada em um estudo histórico não depende da classificação vocal, mas sim do domínio e conhecimento do aparelho fonador. Citando Andrea VON RAMM (2009, p.12-15), mezzo-soprano especializada em interpretação histórica, o canto tem como núcleo central a respiração, ou apoio, do qual não po- demos prescindir. Em torno deste apoio, temos a técnica (registro, agilidade, vibrato), a expressão (sociológica, pessoal, melódica) e a linguagem (significado, caráter, tensão). Para cada resultado estilístico desejado devemos equilibrar a relação entre estes três itens, modificando o percentual dedicado a cada um deles.

\footnotetext{
Um bom músico deve render-se a todos os personagens que deseja retratar. Como um ator habilidoso, ele deverá desempenhar o papel do orador, acreditar-se no local onde os diferentes eventos que deseja descrever acontecem, e participar destes eventos como o fazem aqueles que neles estão envolvidos. Deve declamar bem 0 texto, pelo menos para si mesmo, e sentir quando e em que grau a sua voz deverá elevar-se ou decrescer, para que possa moldar apropriadamente a melodia, a harmonia, a modulação e o movimento (RAMEAU, 1722, p.143).
}

\section{Referências}

BARBOSA, Elmer Cypriano Corrêa. 0 ciclo do ouro. 0 tempo e a música do Barroco católico. Rio de Janeiro: PUC, XEROX, 1978.

BINDER, Fernando e CASTAGA, Paulo. Teoria musical no Brasil: 1734-1854. In: I Simpósio Latino Americano de Musicologia, Curitiba, 10-12 jan. 1997. Anais do I Simpósio Latino-Americano de Musicologia. Curitiba: Fundação Cultural de Curitiba, 1998, p. 198-217.

CASTAGNA, Paulo. A música religiosa mineira no século XVIII e primeira metade do século XIX. In: Apostila do curso História da música brasileira. SP: UNESP, [s.d.].

(coord.). Patrimônio Arquivístico-Musical Mineiro; coordenação musicológica Paulo Castagna; Textos Introdutórios: Júnia Ferreira Furtado, Maria Inês Guimarães, CD1; Governo do Estado de Minas Gerais, 2007.

COTTA, André Guerra (org.). Lobo de Mesquita no Museu da Música de Mariana: homenagem a José Joaquim Emerico Lobo de Mesquita (1746?-1805) no bicentenário de seu falecimento. Mariana: FUNDARQ, 2005.

CYR, Mary. Performing Baroque music. Portland: Amadeus Press, 1998.

DENIS, Arnold. The solo motet in Venice (1625 - 1775). In: Proceedings of the Royal Musical Association, Vol. 106 (1979 - 1980), pp. 56 - 68. Disponível em: <http://www.jstor.org/stable/765926 > Acesso em: 09 out. 2009.

FERNANDES, Cristina. Devoção e teatralidade. As Vésperas de João de Souza Vasconcelos e a prática litúrgico-musical no Portugal Pombalino. Lisboa: Edições Colibri, 2005.

FERREIRA, Aurélio Buarque de Holanda. Novo dicionário eletrônico Aurélio versão 5.0. 3. ed. [s. I.]: Positivo Informática, 2004. CD-ROM. V. 1.1.

FROTA, Lélia Coelho et al. Ataíde. Vida e obra de Manuel da Costa Ataíde. Rio de Janeiro: Editora Nova Fronteira, 1982.

FURTADO, Júnia Ferreira. O livro da capa verde. 0 regimento diamantino de 1771 e a vida no distrito diamantino no período da real extração. São Paulo: Annablume, 2008.

Novas tendências da historiografia sobre Minas Gerais colonial. In: História da Historiografia. No.2.Mar. 2009. p.116-162. Disponível em: <http://www.ichs.ufop.br/rhh/index.php/revista/article/viewFile/11/11 > Acesso em: 31 mar. 2010.

GARBINI, Luigi. Breve storia della musica sacra. Dal canto sinagogale a Stockhausen. Milano: il Saggiatore, 2005.

GARCIA, E. Tratado completo del arte del canto (escuela de Garcia). Tradução de Eduardo Grau. Primeira parte. Buenos Aires: Ricordi Americana, [s.d]. 
GUIMARÃES, Maria Inês Junqueira. L'oeuvre de Lobo de Mesquita. Compositeur brésilien (?1746-1805). 1996. Tese (Doctorat em Histoire de la Musique et Musicologie) - Université de Paris IV - Sorbonne, v.II.

HILLER, Johann A. Treatise on vocal performance and ornamentation. Tradução de Suzanne J. Beicken. Cambridge: Cambridge University Press, 2001. (original de 1780).

JOMMELLI, Niccolò. Care Deus si respiro. Editado por Rolando Scarpa. In: CPDL.org. Disponível em: <http://www2.cpdl. org/wiki/index.php/Care_Deus_si_respiro_(Niccolò_Jommelli)> Acesso em: 20 jul. 2008.

JUNIOR, Robert C. Smith. The colonial architecture of Minas Gerais in Brazil. The Art Bulletin. Vol. 21, No. 2, Jun., 1939, p. 110-159, 1939. Disponível em: <http://www.jstor.org/stable/3046628> Acesso em: 08 abril 2010.

LANGE, Francisco Curt. História da Música na Capitania Geral das Minas Gerais. Vila do Príncipe do Serro Frio e Arraial do Tejuco. Belo Horizonte: Conselho Estadual de Cultura de Minas gerais, 1983. v.VIII.

LOBO DE MESOUITA, José Joaquim Emerico. Largo/Altos Missa de Joze Joaquim Mirico [A]. Museu da Música de Mariana. 2008. LOBO DE MESQUITA, José Joaquim Emerico. Missa in Eb. Museu da Inconfidência, Ouro Preto. 2008.

MANCINI, Giambattista. Pratical reflections on the figurative art of singing. Tradução de Pietro Buzzi. Boston: The Gorham Press, 1912.

MAWE, John.Viagens ao interior do Brasil. Tradução de Selena Benevides Viana. Belo Horizonte: Editora Itatiaia, 1978.

MONTEIRO, Maurício. Na esfera dos limites, no círculo das articulações. Música em Minas colonial In: Magalhães, F. (Curadoria); CURTI, A. H. (Coord.). Aleijadinho e seu tempo: fé, engenho e arte. Rio de janeiro: Centro Cultural Banco do Brasil, 2006, p.59-63).

MOREIRA, Dom Gil Antônio. Religiosidade e arte em Minas Gerais no século XVIII. In: Magalhães, F. (Curadoria); CURTI, A. H. (Coord.). Aleijadinho e seu tempo: fé, engenho e arte. Rio de janeiro: Centro Cultural Banco do Brasil, 2006, p.53-57).

OLIVEIRA, Dom Oscar de. Música a serviço da arte e da fé. In: I Encontro Nacional De Pesquisa Em Música. 1984. Mariana. I encontro nacional de pesquisa em música. Belo Horizonte: Imprensa Universitária, 1984. p.21-36.

OXFORD MUSIC ONLINE. Disponível em: < http://www.oxfordmusiconline.com >.

PEDROSO, Manoel de Moraes. Compendio musico, ou arte abreviada [...]. Porto: Officina Episcopal do Capitão Manoel Pedroso Coimbra, 1751.

PEREZ, David. Messe. Kyrie, Gloria, Credo, Sanctus,Agnus Dei. Soprano, Contralto, Tenore, Basso, Orchestra. sol maggiore. In: Internet culturale Disponivel em: <http://www.internetculturale.it//bdi-ntc/digital/risorsadigitale. jsp?magid=oai:www.int...> Acesso em 11 set. 2009.

PIRES, Sérgio Macedo. Sources, style and context for the Te Deum of José Joaquim Emerico Lobo de Mesquita (1746?1805): A critical edition. 2007. Tese (Doctor of Musical Arts). College of Fine Arts, Boston University.

QUANTZ, J. J.. On playing the flute. Tradução de Edward R. Reilly. New York: Schirmer Books, 1966.

RAMEAU, Jean-Philippe. Traité de I'harmonie. Reduite à ses principe naturels. Paris: L'imprimiere de Jean Baptiste Cristophe Ballard, 1722.

RAMM, Andrea Von. Singing early music. In: Early Music, Vol. 4, No. 1 (Jan., 1976), p. 12-15. Oxford University Press. Disponivel em: < http://www.jstor.org/stable/3126016 > Accesso em: 01 jun. 2009.

RAMOS, Donald. Do Minho a Minas. Revista do Arquivo Público Mineiro. Belo Horizonte, v. 44, n. 1, jan./jun., p.132-153, 2008.

ROCHA, Edilson. A missa grande de Antonio dos Santos Cunha: influências operísticas na obra de um compositor colonial mineiro. Per Musi. Belo Horizonte, n. 18, 2008, p.52-58.

ROMEIRO, Adriana; BOTELHO, Angela Vianna. Dicionário histórico das Minas Gerais. Período colonial. Belo Horizonte: Autêntica, 2003.

RÓNAI, Laura. Tabela de afetos. [Rio de Janeiro], [s.d.].

SAINT-HILAIRE, Auguste de. Viagem pelas Províncias do Rio de Janeiro e Minas Gerais. Tradução de Vivaldi Moreira. Belo Horizonte: Editora Itatiaia, 2000. v. 4.

Viagem pelo Distrito dos Diamantes e Litoral do Brasil. Tradução de Leonam de Azeredo Penna. Belo Horizonte: Editora Itatiaia, 1974. v. 5.

. Voyage dans les district des diamans et sur le littoral du Brésil. Paris: Librairie Gide, 1833. Tome premier.

SILVA, Handel Cecilio Pinto da. O órgão setecentista da Igreja do Carmo de Diamantina. Seus enigmas e sua estreita ligação com o órgão de Córregos. 2008. Dissertação (Mestrado em Música) - Instituto de Artes, Universidade Estadual de Campinas.

SOCIEDADE BRASILEIRA DE CARDIOLOGIA. Publicação eletrônica [mensagem pessoal]. Mensagem recebida por conline@ cardiol.br em 24 out. 2009. 
SODRÉ, Nelson Werneck. A imprensa colonial. In: História da Imprensa no Brasil. 4a. ed. Rio de Janeiro: Mauad editora, 1999. p.17-18.

STARK, James. Bel canto: a history of vocal pedagogy. Toronto: University of Toronto Press, 2008.

TOSI, Pierfrancesco. Opinions of singers ancient, and modern or observations on figured singing. Tradução de Edward Foreman. Minneapolis: Pro music press, 1986.

TOSI, P. F. Observations on the florid song. Tradução de Galliard (1743). Londres: Michael Pilkington, 1987. Reprint, Caligraving, 2002.

VALADARES, Virgínia Trindade. Elites mineiras setecentistas. Conjugação de dois mundos. Lisboa: Edições Colibri, 2004.

VIAGRANDE, Riccardo. Le forme della musica sacra. Monza: Casa Musicale Eco, 2005.

WEIMER, Eric. Opera seria and the evolution of classical style, 1755-1722. Michigan: University Microfilms Inc., 1984.

WERLANG, Guilherme. Estilo e personalidade na música do ciclo do ouro em Minas Gerais Latin American Music Review / Revista de Música Latinoamericana, Vol. 12, No. 2,(Autumn - Winter, 1991), p. 187-199. Publicado por: University of Texas Press. Disponível em: <http://www.jstor.org/stable/780089 > Acesso em: 13 maio 2008, p. 188.

\section{Leitura Recomendada}

BEHAGUE, Gerard. Música barroca mineira: problemas de fonte e estilística. Universitas $n^{\circ} 2$. Salvador: UFBA. Ja

CULLEN, Thomas Linch. Música sacra: subsídios para uma interpretação musical. Brasília: Musimed, 1983.

DART, Thurston. Interpretação da Música. São Paulo: Livraria Martins Fontes Editora, 1990.

DONINGTON, Robert. The interpretation of early music. New York: Faber and faber: 1963.

DUPRAT, Régis (Coord.). Acervo de manuscritos musicais: coleção Francisco Curt Lange: compositores mineiros dos séculos XVIIle XIX. Belo Horizonte: UFMG, 1991.

GODINHO, Josineia. Do iluminismo ao cecilianismo: a música mineira para a missa nos séculos XVIII e XIX. 2008. Dissertação (Mestrado em Música). Escola de Música, Universidade Federal de MG.

HEARTZ, Daniel. Music in European capitals: the gallant style, 1720-1780. New York: W. W. Norton \& Company, Inc., 2003. HENDERSON, W. J. Early history of singing. New York: Longmans Green and Company, 1921.

LOBO DE MESQUITA, José Joaquim Emerico. Quoniam. Editado por Katya Oliveira. 2009.

MILLER, Richard. On the art of singing. New York: Oxford University Press, 1996.

NEUMANN, Frederick. Ornamentation in baroque and post-baroque music. With special emphasis on J. S. Bach. Princeton: Princeton University Press, 1983.

NOGUEIRA, Caio Benévolo Sierra. Vieira e Bach: a ubiquidade do púlpito. 1998. Dissertação (Mestrado em Ciência da Literatura). Faculdade de Letras, Universidade Federal do Rio de Janeiro.

PACHECO, Alberto. O canto antigo italiano: uma análise comparativa dos tratados de Pier Tosi, Giambattista Mancini e Manuel P. R. Garcia. São Paulo: Annablume; FAPESP, 2006. SADIE, Stanley (edição). Rethoric and music. In: The New Grove Dictionary of music and musicians. v. 15, London: Macmillan Publishers Limited, 1980. p.793-803.

PEREZ, David. Qui sedes. Editado por Katya Oliveira. 2009.

\section{Notas}

$1 \quad$ Pier Francesco Tosi (ca.1653-1732) - Importante cantor castrato em seu tempo. Em 1732 escreveu o seu tratado de canto Opinioni de' cantori antichi e moderni (1723) que foi traduzido para o inglês em 1742 como Observations on the Florid Song por Johann Ernst Galliard e em 1757 para 0 alemão como Anleitung zur Singkunst, por Johann Friedrich Agricola (OXFORD MUSIC ONLINE).

2 Giambattista Mancini (1714-1800) - Castrato e mestre de canto na Corte Imperial de Viena. Escreveu seu influente tratado de canto Pensieri, e riflessioni pratiche sopra il canto figurato em 1774 (OXFORD MUSIC ONLINE).

3 Johann Adam Hiller (1728-1824) - Compositor e regente alemão. Escreveu o seu tratado Anweisung zum musikalish-zierlichen Gesange em 1780. Considerado o criador do Singspiel, um tipo de ópera alemã. Professor de música e incentivador da educação musical para as mulheres (OXFORD MUSIC ONLINE).

4 Johann Joachim Quantz (1697-1773) - Flautista e compositor alemão, foi contratado como professor, em 1728, pelo então coroado Príncipe Frederico da Prússia, em Dresden. Entrou para o serviço real como compositor, musico de câmara e diretor musical após Frederico tornar-se rei. Excelente escritor e professor e um grande flautista virtuoso de seu tempo (OXFORD MUSIC ONLINE).

5 PEDROSO, Manoel de Moraes. Compendio musico, ou arte abreviada [...]. Porto: Officina Episcopal do Capitão Manoel Pedroso Coimbra, 1769. 47p. Segunda edição, pertencente aos acervos dos Maestros José Aniceto da Cruz e de seu filho, Francisco Solano Aniceto da Cruz (1895-1970), músicos de família originária do Alto do Rio Doce, que atuaram na cidade mineira de Piranga nos séculos XIX e XX (BINDER, 1998, p.206). 
7 Confrarias, arquiconfrarias e ordens terceiras formadas por leigos.

8 Padres que vivem no século, ou no mundo, não pertencendo a uma ordem religiosa (FERREIRA, 2004).

9 Manuel da Costa Ataíde (1762-1830) - Nascido em Mariana, MG, foi um importante artista do Barroco mineiro, atuando como pintor, dourador, encarnador (aquele que pinta imagens de santos de modo que pareçam reais) e entalhador (FROTA, 1982).

10 Dom Oscar de Oliveira (1912-1997) - Bispo da Arquidiocese de Mariana, assumiu o trono episcopal após a morte de Dom Helvécio. Instituiu o Museu Arquidiocesano de Arte Sacra e a Gráfica Dom Viçoso. Renunciou ao cargo de Arcebispo de Mariana em 1988.

11 Paulo Castagna - Professor Assistente da Universidade Estadual Paulista Júlio de Mesquita Filho (UNESP), trabalhando principalmente com a música brasileira anterior ao século XX, com destaque para a música religiosa mineira dos séculos XVIII e XIX.

12 Segundo Curt Lange (1903-1977), Geraldo Dutra de Moraes apresenta, em "seu folheto intitulado Música Barroca Mineira", sem qualquer prova documental, dados a respeito da origem de Lobo de Mesquita: "(...) nasceu na Vila do Príncipe do Serro do Frio a 12 de outubro de 1746 , sendo filho natural de Joseph Lobo de Mesquita e da sua escrava Joaquina Emerenciana. Registro do Padre Simão Pacheco, Vigário da Matriz de Nossa Senhora da Conceição. Teve como professor de música o Padre Manuel da Costa Dantas, mestre de capela (...)." Lange ainda acrescenta ter procurado pelos livros de batismo referentes ao ano de 1746 no Serro, não encontrando qualquer livro que correspondesse aos anos de 1738-1777. Afirma também desconhecer provas da presença do Pe. Manuel da Costa Dantas, primeiro organista da Sé de Mariana, na região do Serro (1983, p. 112-113).

13 Júnia Ferreira Furtado realizou mestrado e doutorado em História Social na USP. Possui vários artigos e livros publicados sobre a história colonial de Minas Gerais.

14 "Regimento Diamantino, editado em agosto de 1771", no qual "a Coroa criou uma administração própria - a Junta Diamantina - (...) subordinada a uma Administração Diamantina sediada na cidade de Lisboa." 0 único exemplar enviado ao Tejuco era "encadernado em marroquim verde", razão de seu nome (FURTAD0, 2008, p. 26).

15 Construtor de órgão.

16 Claudio Monteverdi (1567-1643) - 0 mais importante músico do final do século XVI e início do XVII, sobressaindo-se em quase todos os gêneros do período. Seus livros de madrigais consolidaram o encerramento do período renascentista, cultivando uma nova estética e novos paradigmas estilísticos para o período barroco. Em suas óperas, desenvolveu novas formas de expressão e estruturação do drama musical. Suas coleções de música litúrgica e devocional transcenderam o meramente funcional, explorando a riqueza de expressão do texto e técnicas estruturais contrapontisticas (OXFORD MUSIC ONLINE).

17 Motetos com temas relacionados à Virgem Maria ou ao seu culto (FERREIRA, 2004).

18 Se preciso a solo é o que se segue adiante.

19 Em cartina: trecho a ser realizado a partir de cópia separada, podendo ser executada obra de outro autor (ROCHA, 2008, p.53).

20 Forma musical que prevaleceu no periodo barroco, escrita para solista com acompanhamento de instrumentos. Consiste em uma forma ternária, com uma seção A, uma seção B contrastante, geralmente na região do sexto e/ou terceiro graus (WEIMER, 1984, p.12), e a repetição da primeira (seção A).

21 Seção polifônica com diálogo entre os violinos.

22 Capacidade de iniciar a nota em piano, crescer e decrescer.

Katya Beatriz de Oliveira é mestranda em práticas interpretativas (performance histórica) na UNIRIO, sob a orientação de Laura Rónai. Sua formação inclui o bacharelado em canto lírico na UFMG, aperfeiçoamento em ópera nos EUA como bolsista do Ministério da Cultura, orientação com o Prof. Carmo Barbosa (SP) e a realização de aperfeiçoamento interpretativo da ópera O Elixir do amor, com o Maestro Sergio Oliva, em Roma (Itália). Foi solista frente a diferentes orquestras, no papel de Violeta (La Traviata), Adina (O elixir do Amor), Serpina (La serva padrona), dentre outros. Atua principalmente como intérprete da música brasileira do século XVIII e XIX e de compositores europeus afins, integrando o grupo Coro e Orquestra Domine Maris, com o qual gravou o CD Creator Alme. Participou como solista na gravação dos CDs $10^{\circ} \mathrm{Festival}$ Internacional de Música Colonial Brasileira e Música Antiga (Juiz de Fora-MG), Ensemble Cum Sancto Spiritus (VitóriaES) e no CD Cantigas de Roda (Vitória-ES). Em 2008 publicou quatro edições de manuscritos musicais no livro A música sacra em Viçosa.

Laura Rónai Flautista formou-se em Licenciatura em Música pela UNIRIO e em Flauta pela State University of New York. Obteve título de mestrado na City University of New York e de doutorado em Práticas Interpretativas na UNIRIO. Ministrou cursos no Real Conservatório Superior de Madrid e, nos EUA, nas universidades de Rutgers e Princeton. Visitou a Inglaterra, a convite do British Council, e tocou recitais nos EUA e na Europa. Toca em duo com a pianista Ruth Serrão e com a cravista Sula Kossatz, com quem integra os grupos de câmara Sine Nomine e Re-Toques. Dirige a Orquestra Barroca da UNIRIO e é crítica musical para as revistas norte-americanas Fanfare e Early Music America. Atualmente é responsável pela cadeira de flauta transversal e chefe do Departamento de Canto e Instrumentos de Sopro da UNIRIO, além de ser docente do Programa de Pós Graduação em Música da mesma instituição. 